\title{
PENGEMBANGAN PENDIDIKAN NONFORMAL BIMBEL ENGGON SIN_AU_QU DENGAN METODE SOCIOPRENEUR DI ERA PANDEMI
}

\author{
Dyah Puspita Indah Budi Sari Wulan ${ }^{1}$, Nurleila Jum'ati ${ }^{2}$, Hardo Wahyudi ${ }^{3}$, Risca Ayu \\ Rachmania $^{4}$, Lusy Nur Miftachul Jannah ${ }^{5}$, Mochamad Syahrul Gunawan ${ }^{6}$, Haris Priambodo ${ }^{7}$ \\ ${ }_{1,2,3,4,5,6,7}$ Universitas Wijaya Putra \\ nurleila@uwp.ac.id
}

\begin{abstract}
Abstrak
Pandemi Covid-19 menimbulkan dampak pada semua sendi kehidupan masyarakat, salah satunya adalah banyaknya fresh graduate lulusan strata 1 belum mendapatkan pekerjaan. Di sisi yang lain perubahan metode pembelajaran daring secara spontan untuk menekan penyebaran virus menimbulkan kendala dan hambatan bagi siswa dan orang tua dalam beradaptasi. Orang tua cenderung menggunakan tenaga bimbingan belajar nonformal untuk menunjang tingkat pemahaman materi yang diberikan di sekolah untuk mengatasi kendala tersebut. Bimbel Enggon Sin_Au_Qu merupakan lembaga penyedia jasa pendidikan nonformal dengan jangkauan wilayah Surabaya, Sidoarjo, Gresik, Malang, Semarang bahkan Kalimantan mendapatkan dampak positif dari pembelajaran daring dengan mengalami peningkatan permintaan jasa tutor sehingga menyerap tenaga terdidik tersebut. Penyerapan tenaga terdidik tersebut dengan basis metode sociopreneur. Permasalahan yang dialami oleh manajamen adalah tutor yang mayoritas berasal dari fresh graduates. Bimbel Enggon Sin_Au_Qu melakukan metode pendampingan dengan memfasilitasi tutor untuk mengikuti training online pengembangan SDM, pembenahan manajemen Enggon Sin_Au_Qu dalam mengelola tutor dan pengguna jasa serta mengembangkan sistem promosi untuk memperluas pemasaran. Hasil yang dicapai sebagai sociopreneurship adalah : 1) Pengembangan potensi sumber daya tutor, 2) Sistem manajemen menjadi terkoordinir 3) Bimbel Enggon Sin_Au_Qu dikenal oleh masyarakat luas. Dengan demikian, Enggon Sim_Au_Qu sebagai wadah usaha yang mampu menumbuhkan potensi ekonomi yang dapat dinikmati berbagai pihak yang terlibat.
\end{abstract}

Kata Kunci : Pendidikan, Nonformal, Tutor, Pandemi.

\section{PENDAHULUAN}

Pandemi Covid-19 menyebabkan dampak yang cukup signifikan terhadap berbagai sektor sendi kehidupan manusia di semua belahan bumi. Beberapa sektor seperti sektor ekonomi, bisnis, pendidikan, pariwisata, industri, kesehatan dan lain sebagainya. Pemerintah Indonesia berupaya untuk mengurangi penyebaran virus tersebut dengan menerapkan berbagai kebijakan yaitu sistem pembelajaran yang dilakukan secara daring (dalam jaringan), work from home (WFH), Pembatasan Sosial Berskala Besar (PSBB), Perberlakukan Pembatasan Kegiatan Masyarakat (PPKM) dan pemberlakuan protokol kesehatan yang ketat dalam berbagai sektor menyebabkan perubahan besar yang 
dirasakan oleh masyarakat, baik ekonomi, sosial, budaya termasuk pendidikan. (Jum'ati et al., 2021)

Efek yang paling besar dirasakan adalah semakin banyak jumlah Pemutusan Hubungan Kerja (PHK) massal untuk meminimalisir anggaran, perputaraan barang dan uang yang melambat, serta semakin minimnya lapangan pekerjaan. Persaingan kerja menjadi semakin ketat apalagi dengan adanya fenomena pandemi Covid-19 yang menghambat terserapnya tenaga kerja dari fresh graduate SMA/SMK atau Sarjana. (Sa'adah et al., 2019) Berdasarkan data Badan Pusat Statistik (BPS) tercatat jumlah pengangguran terbuka di Indonesia mencapai 8.746.008 orang pada Februari 2021. Berikut klasifikasi Tingkat Pengangguran Terbuka (TPT) menurut kelompok usia pada Februari (2020) dan Februari (2021).

\section{Tingkat Pengangguran Terbuka Menurut Usia Pada Tahun 2020 Dan 2021}

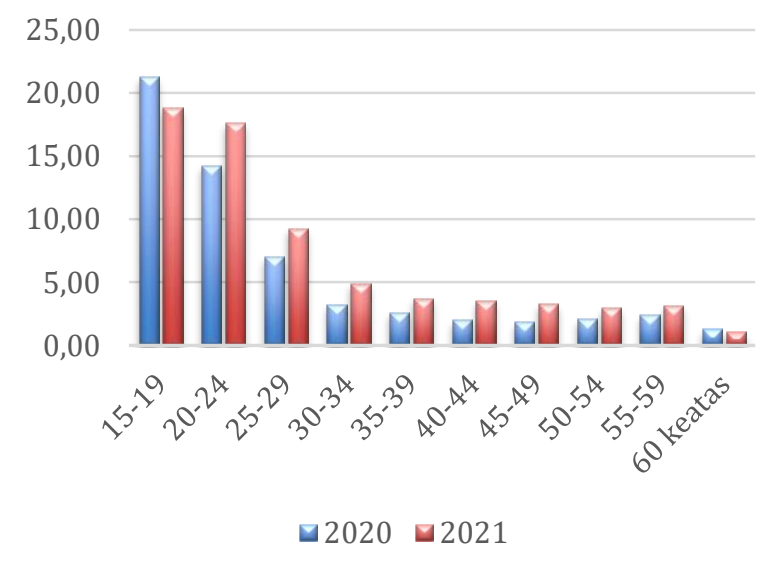

Gambar 1. Klasifikasi Tingkat Penganguran Terbuka (TPT) menurut kelompok usia tahun 2020 dan 2021

Berdasarkan gambar 1 diatas, data pengangguran terbesar terjadi pada kelompok anak muda yang berusia 15-19 tahun namun pada usia tersebut masih dalam usia wajib belajar (sekolah menengah atas). Sehingga usia pengangguran terbesar berada pada usia 20-29 tahun. Tingkat Pengangguran Terbuka (TPT) pada penduduk usia 20-24 tahun mengalami peningkatan dari tahun
2020 berjumlah 14,3\% naik pada tahun 2021 menjadi $17,66 \%$ dan pada usia 25-29 tahun pada tahun 2020 sebesar $7,01 \%$ naik pada tahun 2021 menjadi $9,27 \%$.

Umumnya anak muda rata-rata memiliki peluang lebih besar menjadi penganguran dibandingkan orang dewasa karena anak muda berada pada masa transisi antara bersekolah dan bekerja. (Corbanese \& Rosas, 2016). Menurut Sziraczki dan Reerink (Wardhana et al., 2019) dalam masa transisi banyak anak muda yang masih belum siap untuk menghadapi perubahan dari pelajar menjadi pekerja yang sejalan dengan presentase Tingkat Penganguran Terbuka (TPT) yang diidentifikasi berdasarkan pendidikan yang dimililikinya. Berikut data tingkat riwayat pendidikan Tingkat Pengangguran Terbuka (TPT) Indonesia terbagi menjadi:

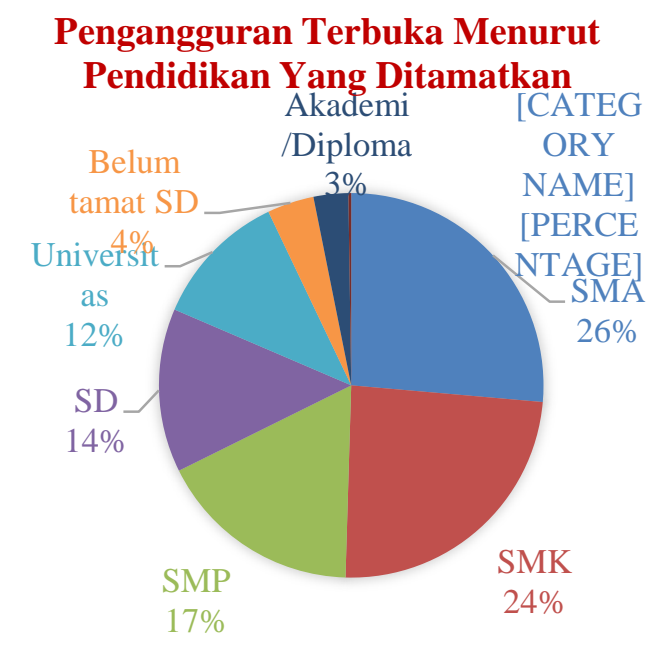

Gambar 2. Klasifikasi Pengangguran Terbuka menurut pendidikan yang ditamatkan

Berdasarkan gambar 2 diatas, pengangguran terbuka berdasarkan tamatan pendidikan berasal dari lulusan SMA sebesar 2,3 juta orang, SMK sebesar 2,1 juta orang, Universitas 999.543 orang, SMP 1,5 juta orang, SD 1,2 juta orang, Akademi/Diploma sebanyak 254.457 orang, belum tamat SD sebanyak 342.734 orang dan belum pernah sekolah sebanyak 20.461 orang. Menurut (Boediono, Budihabsari, 2016) Indonesia memiliki 
isu bonus demografi dimana usia produktif akan mencapai jumlah yang sangat banyak pada beberapa tahun kedepan, sehingga jumlah pengangguran usia muda yang tinggi menjadi permasalahan yang krusial selain ketersediaan lapangan pekerjaan.

Meningkatnya jumlah angka pengangguran yang tidak diimbangi dengan banyaknya lapangan pekerjaan akan menyebabkan persaingan mendapatkan pekerjaan yang layak dan sesuai dengan keahlian akan semakin kuat sehingga memberatkan bagi fresh graduate yang harus mencari pekerjaan sesuai dengan bidang akademik selama berkuliah. Tingginya persaingan tersebut tidak dapat dipungkiri akan berdampak pada kecemasan para mahasiswa fresh graduate apabila mereka tidak kunjung mendapat pekerjaan yang diharapkan. (Sejati \& Prihastuti, 2018)

Untuk mengurangi angka penyebaran Covid-19 pada bidang pendidikan, pemerintah membuat kebijakan untuk menutup sekolah dan mengubah sistem pembelajaran secara daring yang dapat dilakukan dirumah masing-masing siswa. Keadaan tersebut akan berdampak pada kondisi fisik maupun psikis dari siswa yang dapat menyebabkan siswa merasa tugas yang diberikan oleh guru sangat banyak padahal pemberian tugas sama saja dengan pemberian tugas ketika pembelajaran tatap muka. Perbedaan kemampuan yang dimiliki oleh siswa dapat menyebabkan perbedaan keadaan siswa dalam melakukan pembelajaran secara daring sehingga lama kelamaan siswa akan merasa bosan dan tertekan dengan tugas yang diberikan oleh guru disekolah. (Prawanti \& Sumarni, 2020). Dengan adanya sistem pembelajaran daring peran orang tua sebagai pendamping dalam belajar menjadi lebih intens. Terdapat kendala yang dihadapi oleh orang tua dalam sistem pembelajaran daring yaitu tidak semua orang tua menguasau materi yang diberikan oleh guru, terbatasnya fasilitas dan media di lingkungan keluarga dan meningkatnya stress yang dialami oleh orang tua siswa (Tabi'in, 2020). Oleh karena itu orang tua cenderung menggunakan jasa lembaga bimbingan belajar nonformal untuk menunjang tingkat pemahaman materi yang diberikan di sekolah untuk mengatasi kendala tersebut.
Bimbel Enggon Sin_Au_Qu merupakan lembaga bimbingan penyedia jasa pendidikan nonformal yang berlokasi di Jl. Dukuh Pengalangan No. 47 Gresik, berbatasan langsung dengan wilayah Surabaya terutama Surabaya Bagian Barat. Berlokasi di sekitaran pemukiman padat penduduk. Mayoritas masyarakat sekitar merupakan keluarga dengan anak yang masih duduk dibangku Sekolah Dasar. Selain itu, berbatasan langsung dengan wilayah Surabaya Bagian Barat yang merupakan wilayah padat penduduk yang diimbangi dengan banyaknya instansi Pendidikan mulai jenjang SD, SMP, SMA hingga Perguruan Tinggi. Keberadaan Enggon Sin_Au_Qu memberikan kontribusi kepada masyarakat sekitar secara khusus terutama pada masa pandemi, sehingga berdampak pada sistem pendidikan di Indonesia yang dilaksanakan secara daring. Pengguna jasa Enggon Sin_Au_Qu juga tersebar di beberapa daerah meliputi daerah Surabaya, Sidoarjo, Gresik, Malang, Semarang bahkan Kalimantan. Bimbel Enggon Sin_Au_Qu mendapatkan dampak positif dari pembelajaran daring dengan mengalami peningkatan permintaan jasa tutor sehingga membuka peluang kerja bagi fresh graduate. Bimbel Enggon Sin_Au_Qu menjadi wadah bagi fresh graduate yang belum mendapatkan pekerjaan sesuai dengan background pendidikannya.

Dengan mayoritas tutor yang berasal dari fresh graduate menjadi permasalahan tersendiri bagi manajemen bimbel Enggon Sin_Au_Qu. Tutor yang berasal dari fresh graduate dan tidak memiliki background pendidikan sebagai tenaga pengajar akan mengalami kesulitan dalam beradaptasi dengan siswa bimbingannya. Permasalahan yang dihadapi oleh mitra tidak hanya dari tutor yang mayoritas yang berasal dari fresh graduate namun masih belum adanya manajemen usaha yang terkoordinir dari bimbel Enggon Sin_Au_Qu karena usaha tergolong masih baru dan koordinasi antara tutor, siswa dan orang tua masih kurang. Namun pemasaran yang masih terbatas di lingkup kecil dengan orang-orang yang sama menjadi hambatan dalam mengembangkan usaha tersebut. Promosi belum optimal dan belum mampu membangun jejaring pemasaran dengan baik menjadi kendala 
dalam memperluas pemasaran bimbel Enggon Sin_Au_Qu.

Ditinjau dari aspek tersebut, permasalahan yang dihadapi oleh pihak manajemen yaitu: 1) mayoritas tutor berasal dari fresh graduate, 2) usaha bimbel Enggon Sin_Au_Qu merupakan usaha yang baru dirintis sehingga manajemen usaha masih belum terkoordinir, 3) sistem pemasaran yang masih pasif dan konvensional.

\section{METODE}

Bimbel Enggon Sin_Au_Qu melakukan metode pendampingan. Pada metode pendampingan tim terjun langsung ke lapangan dan berkoordinasi dengan manajemen Enggon Sin_Au_Qu untuk menentukan skala prioritas masalah yang akan diselesaikan agar tidak hanya menurut penilaian subyektifitas dari penyusun namun berdasarkan kesepakatan bersama agar permilihan solusi yang ditawarkan benar-benar efektif dan sesuai dengan kebutuhan mitra. Tahapan yang dilakukan dalam kegiatan pengabdian masyarakat adalah: 1) memfasilitasi tutor untuk mengikuti training online pengembangan SDM, 2) pembenahan manajemen Enggon Sin_Au_Qu dalam mengelola tutor dan pengguna jasa, 3) edukasi mengembangkan sistem promosi untuk memperluas pemasaran.

\section{HASIL DAN PEMBAHASAN}

Adapun untuk tahapan pelaksanaan tahapan yang dilakukan dalam kegiatan pengabdian masyarakat adalah:

Tahap 1. Memfasilitasi tutor untuk mengikuti training online pengembangan SDM.

Bimbel Enggon Sin_Au_Qu memiliki tutor yang berjumlah 18 orang yang terdiri dari 10 orang berjenis kelamin perempuan dan 8 orang berjenis kelamin laki-laki yang berusia sekitar 23 hingga 31 tahun dengan background pendidikan lulusan dari Perguruan Tinggi Negeri dan Perguruan Tinggi Swasta. Berikut klasifikasi background pendidikan tutor Enggon Sin_Au_Qu.

\section{Klasifikasi Background Pendidikan Tutor}

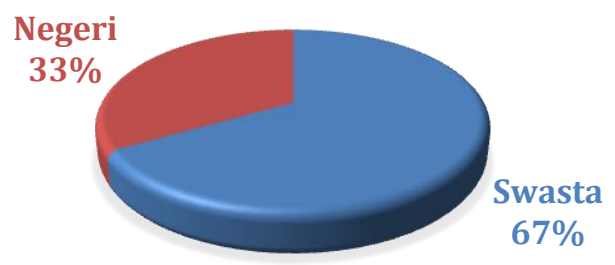

Gambar 3. Klasifikasi Background Pendidikan Tutor

Berdasarkan data gambar 3 diatas tutor yang berasal dari Perguruan Tinggi Negeri sebanyak 33\% yaitu 6 orang tutor dan yang berasal dari Perguruan Tinggi Swasta sebanyak 67\% yaitu 12 orang tutor.

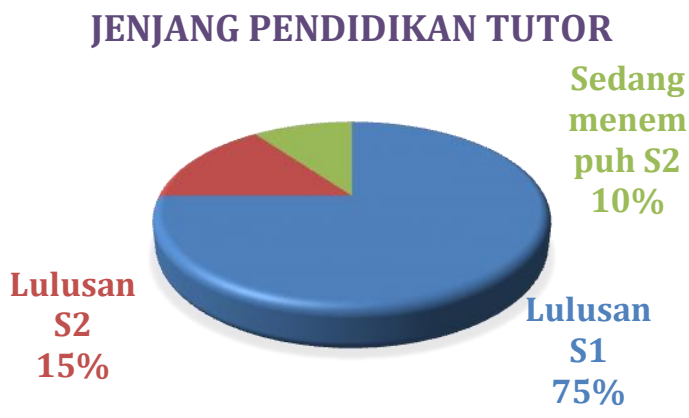

Gambar 4. Jenjang Pendidikan Tutor

Berdasarkan gambar 4 diatas. dari 18 tutor diatas 3 diantaranya adalah lulusan S2, 2 orang sedang menempuh pendidikan S2 dan sisanya lulusan S1. Tutor pada bimbingan belajar Enggon Sin_Au_Qu merupakan lulusan dari pendidikan S1 dan S2 dengan latar belakang pendidikan yang berbeda-beda yang terdiri dari :

Tabel 1. Background Pendidikan Tutor Enggon Sin_Au_Qu

\begin{tabular}{|l|l|l|}
\hline No & \multicolumn{1}{|c|}{ Nama } & \multicolumn{1}{c|}{ Lulusan } \\
\hline 1 & Hardo Wahyudi & $\begin{array}{l}\text { S1 Teknik Mesin , S2 } \\
\text { SDM }\end{array}$ \\
\hline 2 & Tri Wahyuni & S1 PAI, S1 PAUD \\
\hline
\end{tabular}

Ekonomi, Sosial dan Budaya 1020 


\begin{tabular}{|l|l|l|}
3 & Yahya Ramadoni & S1 Pend. Bahasa Inggris \\
\hline 4 & $\begin{array}{l}\text { Nadia Risqi } \\
\text { Purwanto }\end{array}$ & S1 Sastra Ingris \\
\hline 5 & Ahmad Affandi & $\begin{array}{l}\text { S1 Pend. Teknologi } \\
\text { Informasi }\end{array}$ \\
\hline 6 & $\begin{array}{l}\text { Listianty Misa } \\
\text { Karyana }\end{array}$ & S1 Multimedia \\
\hline 7 & Risca Nur Hidayati & S1 Akuntansi \\
\hline 8 & Angga Satriawan & S1 Teknik Kimia \\
\hline 9 & Suryo Atmojo & $\begin{array}{l}\text { S1 dan S2 Sistem } \\
\text { Informasi }\end{array}$ \\
\hline 10 & Nur Aini Azizah & S1 Akuntansi \\
\hline 11 & Risca Ayu & S1 Manajemen \\
\hline 12 & Dyah Puspita & S1 Teknik Industri \\
\hline 13 & Indra Gumilar & S1 Biologi \\
\hline 14 & Shela & S1 Biologi \\
\hline 15 & Ayu & $\begin{array}{l}\text { S1 Pendidikan Bahasa } \\
\text { Inggris }\end{array}$ \\
\hline 16 & Pretty & $\begin{array}{l}\text { S1 Pendidikan } \\
\text { Matematika }\end{array}$ \\
\hline 17 & Ardi & S2 Kimia \\
\hline 18 & Angga Sandika & S1 IESP \\
\hline & & \\
\hline
\end{tabular}

Berdasarkan data table 1 diatas tutor yang memiliki background pendidikan lulusan ilmu pendidikan $27,78 \%$ yaitu sebanyak 5 orang dan sisanya berasal dari background pendidikan ilmu murni 72,22\% yaitu sebanyak 13 orang. Mayoritas Tutor Enggon Sin_Au_Qu merupakan fresh graduate dan berasal dari lulusan ilmu murni sehingga membutuhkan training pengembangan SDM. Bimbel Enggon Sin_Au_Qu memfasilitasi tutor untuk mengikut pelatihan diklat online APKS PGRI Jawa Timur 2020 yang terdiri dari beberapa tahap pelatihan yaitu : 1) Pembuatan Video Pembelajaran Berbasis Power Point (dilaksanakan pada tanggal 1-6 September 2020), 2) Pembuatan Blog Pembelajaran Itu Mudah (dilaksanakan pada tanggal 28 September - 1 Oktober 2021), 3) Membuat Soal Kreatif Dan Menyenangkan Menggunakan Quizizz (dilaksanakan pada tanggal 23 dan 26 Oktober 2020), 4) Penyusunan Soal Model Asesmen Kompetensi Minimum (AKM) Yang Menarik Menggunakan Aplikasi iSpring (dilaksanakan pada tanggal 16 dan 18 Desember 2020).

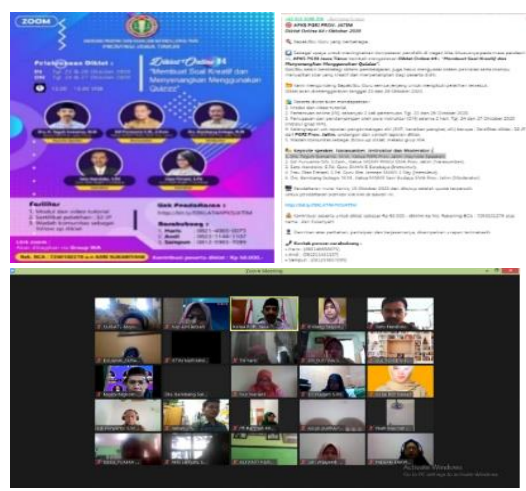

Gambar 5. Pelaksanaan Training APKS PGRI Provinsi Jawa Timur

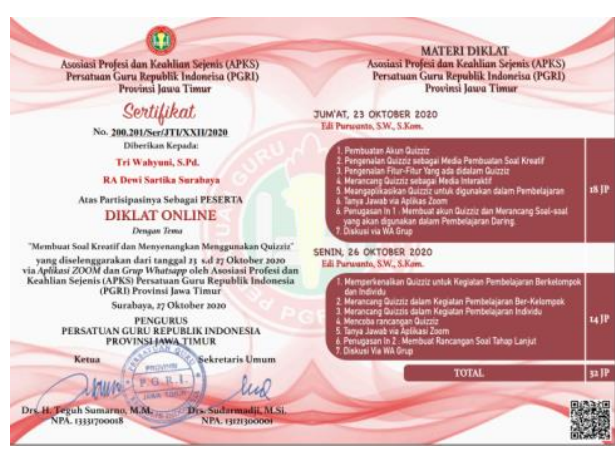

Gambar 6. Sertifikat Pelatihan APKS PGRI Provinsi Jawa Timur

Tim manajemen Enggon Sin_Au_Qu juga mengikuti webinar untuk mengembangkan kapasitas tentang manajemen usaha dan pemasaran produk jasa, adapun untuk webinar yang diikuti oleh manajemen adalah 1) Pemanfaatan media sosial Facebook sebagai media pemasaran, 2) pemanfaatan digital marketing untuk UMKM 


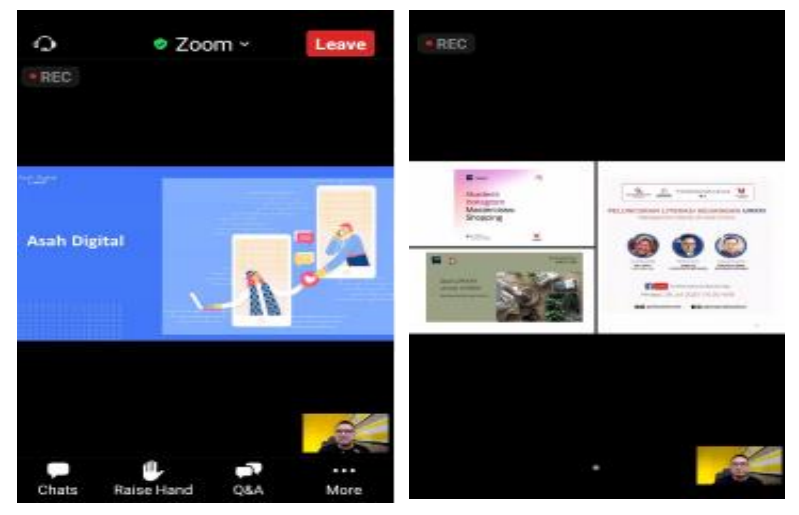

Gambar 7. Mengikuti Webinar Zoom "Studium General With Facebook"

Tahap 2. Pembenahan manajemen Enggon Sin_Au_Qu dalam mengelola tutor dan pengguna jasa

Usaha jasa merupakan setiap tindakan atau kegiatan yang dapat ditawarkan oleh satu pihak kepada pihak lain, pada dasarnya tidak berwujud dan tidak mengakibatkan perpindahan kepemilikan apapun. (Kotler, 2013). Dalam usaha jasa selalu ada aspek interaksi antara pihak kosumen dan pemberi jasa, meskipun pihak-pihak yang terlibat tidak selalu menyadari. (Lupiyoadi dan Hamdani, dalam Pradina, 2020). Bimbingan belajar merupakan usaha jasa, sehingga penilaian positif dari pelanggan ataupun mitra (tutor) menjadi prioritas dalam perkembangan usaha. Menurut Daryanto dan Setyobudi (2014), kepuasan konsumen dipengaruhi oleh kualitas produk atau barang-barang yang diberikan pada pelanggan dalam proses penyerahan jasa, kualitas jasa, persepsi atas harga, serta faktor situasional dan personal. Peningkatan kualitas layanan dan kualitas produk jasa merupakan salah satu strategi bisnis yang ditekankan pada pemenuhan keinginan konsumen.

Produk jasa yang ditawarkan oleh bimbel Enggon Sin_Au_Qu antara lain :

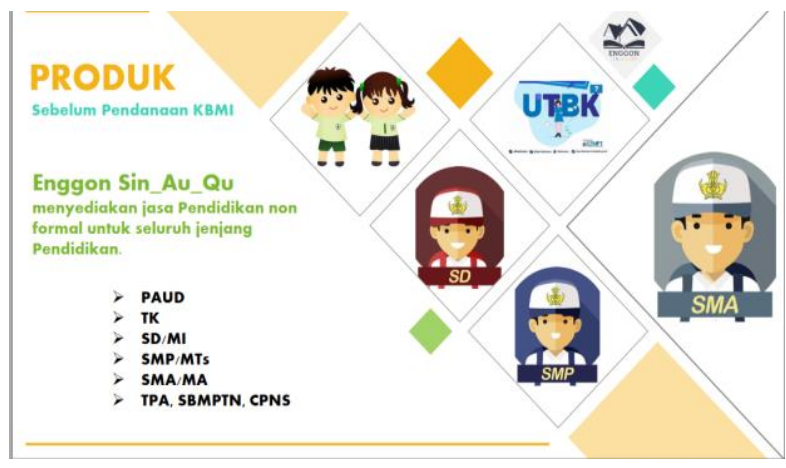

Gambar 8. Produk bimbel Enggon Sin_Au_Qu

Bimbel Enggon Sin_Au_Qu menyediakan jasa pendidikan nonformal untuk berbagai jenjang pendidikan dengan tipe kelas ajar terbagi menjadi dua yaitu : 1) kelas premium yang terdiri dari maksimal 2 orang/tutor, 2) kelas semi premium yang terdiri dari maksimal 5 orang/tutor. Dengan semakin banyaknya tutor di Enggon Sin_Au_Qu dan arahan yang dilakukan oleh tim, maka produk Enggon Sin_Au_Qu mengalami inovasi yaitu dengan menambahkan program diluar materi umum yaitu : 1) Programmer Class, dengan fokus pembelajaran basic programmer dan advance programmer. 2) Accounting Class, dengan fokus pembelajaran basic accounting dan advance accounting.

Sistematika alur pembelian jasa Bimbel Enggon Sin_Au_Qu dapat dilakukan secara online ataupun offline. Adapun alur pembelian jasa bimbel Enggon Sin_Au_Qu adalah sebagai berikut :

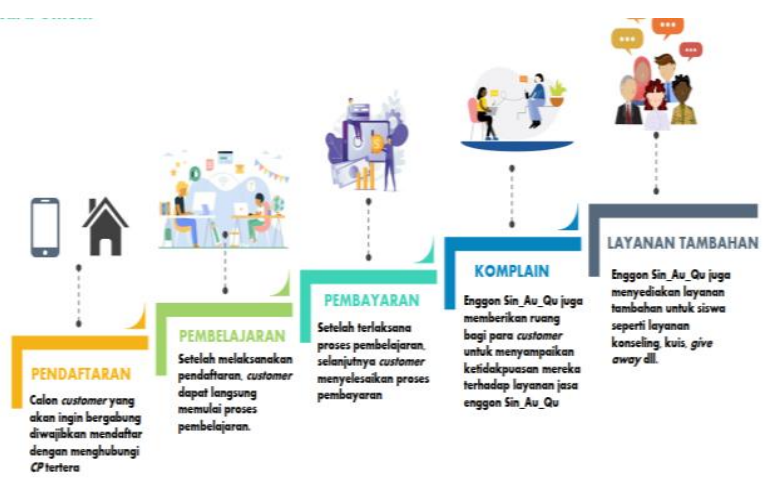


Gambar 9. Alur pembelian jasa Bimbel Enggon

$$
\text { Sin_Au_Qu }
$$

Berdasarkan gambar 9 tersebut sistematika alur pembelian jasa terdiri dari : 1) Pendaftaran yang dapat dilakukan baik secara offline ataupun online, 2) Melakukan proses pembelajaran sesuai dengan paket yang dipilih, 3) Bimbel Enggon Sin_Au_Qu tidak ada biaya pendaftaran dan pembayaran akan dilakukan setelah pelaksanaan proses pembelajaran. Sistem pembayaran dapat dilakukan secara tunai, transfer melalui rekening BRI dan Bank Jatim ataupun menggunakan platform e-wallet seperti Dana, Go-Pay, dan LinkAja. 4) Penanganan komplain, Enggon Sin_Au_Qu juga memberikan ruang bagi para customer untuk menyampaikan ketidakpuasan mereka terhadap layanan jasa Enggon Sin_Au_Qu. 5) Enggon Sin_Au_Qu juga menyediakan layanan tambahan untuk siswa seperti layanan konseling, kuis, give away, dan lainnya.

Pendaftaran siswa baru di Enggon Sin_Au_Qu dilaksanakan secara offline dengan mengunjungi office yang terletak di Jl. Dukuh Pengalangan No. 47 Gresik (Dekat Bukit Palma) dan online dengan menghubungi Contact Person via whatsapp dengan melakukan pengisian formulir melalui google form, pengisian formulir melalui website untuk memudahkan pelanggan mengakses data dari bimbel Enggon Sin_Au_Qu.

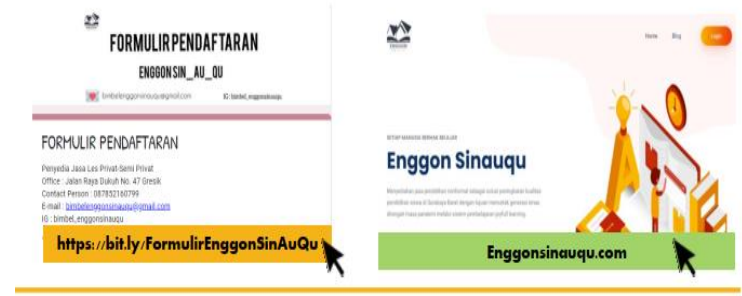

Gambar 10. Pendaftaran menggunakan sistem online via google form dan website

Langkah untuk mengetahui tingkat kepuasan konsumen merupakan faktor penting yang harus diperhatikan untuk menjawab voice of customer (suara konsumen), sehingga didapatkan kemampuan untuk menjawab keinginan konsumen tersebut. Adapun berbagai metode yang dapat digunakan untuk mengukur kepuasan pelanggan, metode tersebut antara lain (Yamit dalam Jutisa, dkk. 2018) antara lain : 1) Sistem Pengaduan. Dengan memberikan kesempatan kepada pelanggan untuk memberikan saran, keluhan, dan bentuk ketidakpuasan lainnya dengan cara menyediakan kotak saran, 2) Survey Pelanggan atau Konsumen. Survey pelanggan atau konsumen merupakan cara yang umum digunakan dalam mengukur kepuasan pelanggan, misalnya, melalui surat pos, telepon, atau wawancara secara langsung, 3) Panel Pelanggan atau Konsumen. Perusahaan mengundang pelanggan atau konsumen yang setia terhadap produk dan mengundang pelanggan yang telah berhenti membeli atau telah pindah menjadi pelanggan perusahaan lain. Enggon Sin_Au_Qu melayani komplain pelanggan baik secara langsung ataupun online. Setelahnya akan dilaksanakan konseling perihal keluhan baik dari siswa ataupun orang tua sehingga dapat ditindak lanjutin dan manajemen akan melakukan pembenahan dan evaluasi secara internal. Untuk menjaga kepercayaan para customer, Enggon Sin_Au_Qu memberikan feedback berupa merchandise dan tambahan waktu belajar bagi siswa.

\section{Tahap 3. Edukasi mengembangkan sistem promosi untuk memperluas pemasaran.}

Pemberlakuan kebijakan pemerintah tentang Pembatasan Sosial Berskala Besar (PSBB) dan Perberlakukan Pembatasan Kegiatan Masyarakat (PPKM) secara langsung menuntut para pelaku usaha untuk ikut menyesuaikan diri seiring dengan persaingan yang juga ikut berubah. Pelaku usaha berinovasi memasarkan produk ataupun jasanya melalui pemanfaatan teknologi digital. Pemasaran melalui pemanfaatan eknologi digital atau yang biasa disebut sebagai digital marketing dapat membantu pelaku usaha dalam hal mempromosikan dan memasarkan produk dan jasa mereka tanpa adanya batasan jarak, waktu dan cara komunikasi. (Hardilawati, 2020). Sejalan dengan (Hendrawan et al., 2019) yang menyatakan 
kebenaran digital marketing yang dapat mempengaruhi secara positif dan signifikan terhadap peningkatan kondisi pemasaran produk UMKM. Strategi pemasaran merupakan komponen yang berpengaruh dan mampu mengendalikan keberhasilan masyarakat dalam menerima produk, namun perhatian para pelaku UMKM masih minim terkait dengan strategi pemasaran sehingga berakibat banyaknya bisnis UMKM yang tersendat bahkan dimasa pandemi Covid-19 mengalami kesulitan dalam penjualan produk ataupun jasa. (Nugrahani, 2015). Meskipun kualitas produk atau jasa yang dihasilkan baik namun jika produk ataupun jasa tidak dapat dipasarkan dengan baik maka nilai jual produk tersebut juga akan rendah. (Bakhri \& Futiah, 2020). Bimbel Enggon Sin_Au_Qu beradaptasi dengan kondisi sekarang sehingga dalam sistem pemasaran dilaksanakan secara direct selling maupun indirect, adapun pemasaran direct antara lain: 1) membuat flyer yang berisikan profil tentang Enggon Sin_Au_Qu disertai dengan rincian produk dan biaya jasa, 2) membuat roll banner dan bekerjasama dengan koperasi Edu Café Universitas Wijaya Putra untuk menempatkan roll banner yang berisikan informasi garis besar produk.

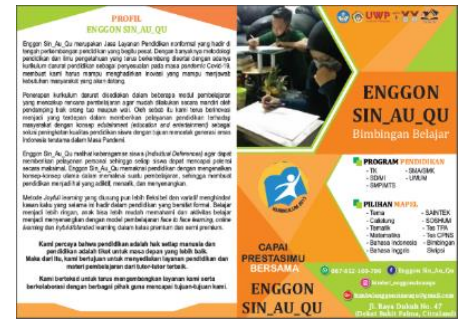

Gambar 11. Flyer Enggon Sin_Au_Qu

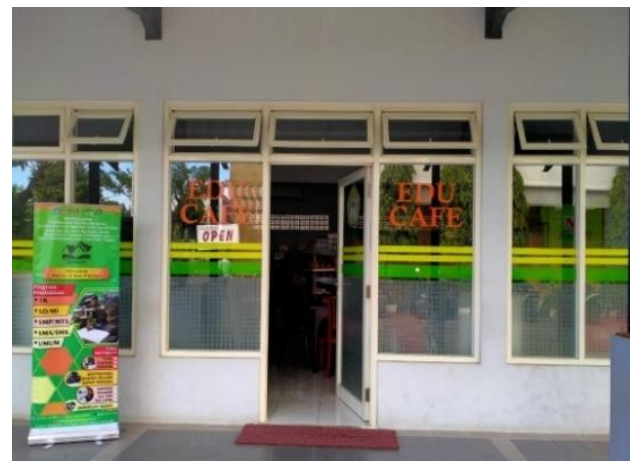

\section{Gambar 12. Pemasangan roll banner}

Pemasaran secara online melalui media merupakan langkah tepat yang harus dilakukan oleh parah pelaku usaha strategi yang diterapkan oleh para pelaku usaha harus dilakukan secara optimal agar produk yang dihasilkan dapat diterima oleh masyarakat dengan memberikan keterangan yang jelas dan dapat dipercaya konsumen. (Suswanto dan Setiawan, 2020). Berdasarkan laporan berjudul digital 2021 : The Latest Insights Into The State Of Digital, dijelaskan bahwa 202,6 juta penduduk Indonesia menggunakan internet dengan total 170 juta penduduk di Indonesia telah menggunakan media sosial. (Stephanie, 2021). Media sosial yang banyak digunakan oleh pelaku usaha dalam memasarkan produksinya dapat terlihat pada grafik berikut :

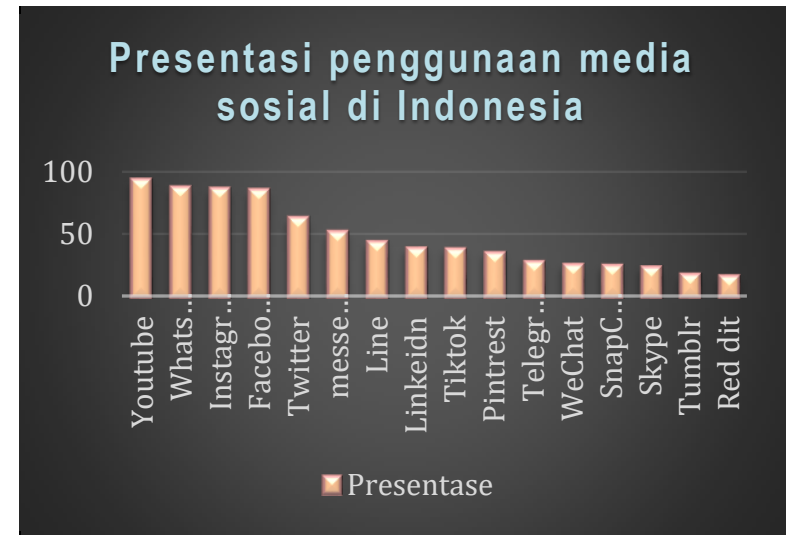

Gambar 13. Pengguna media sosial di Indonesia

Berdasarkan gambar diatas aplikasi media sosial yang paling banyak digunakan di Indonesia yaitu Youtube, disusul oleh WhatsApp, Instagram, Facebook, lalu Twitter secara berturut-turut. Ratarata orang Indonesia menghabiskan 3 jam 14 menit setiap hari untuk mengakses media sosial dan ratarata orang Indonesia ternyata memiliki 10 akun media sosial per orang. Selain itu, 60 persen pengguna media sosial memakainya untuk bekerja seperti menjalin relasi dan menjalankan bisnis. (Stephanie, 2021)

Adapun indirect selling bimbel Enggon Sin_Au_Qu terdiri dari: 1) memanfaatkan media sosial Facebook, Instagram dan Youtube sebagai 
sarana untuk menyampaikan informasi, 2) memanfaatkan website sebagai sarana komunikasi dengan masyarakat secara umum, koordinasi tutor, dan sebagai media pembelajaran bagi siswa Enggon Sin_Au_Qu.

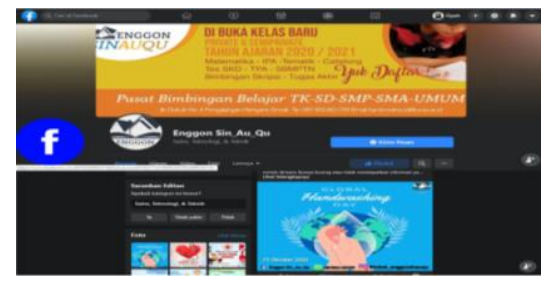

Gambar 14. Pemasaran sosial media facebook

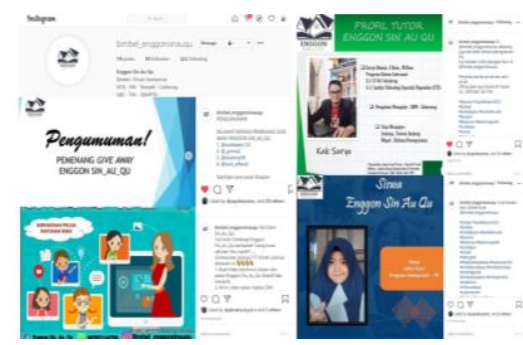

Gambar 15. Pemasaran sosial media Instagram

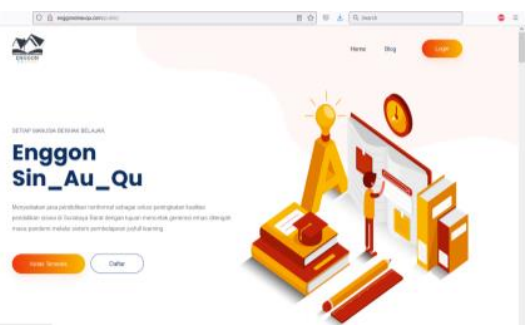

Gambar 16. Pemasaran menggunakan website

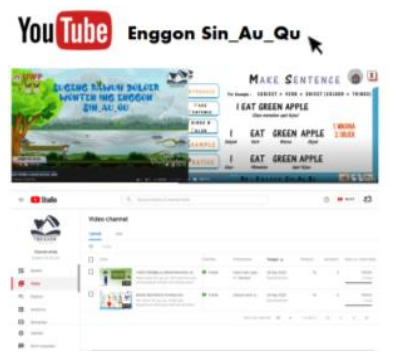

Gambar 17. Pemasaran sosial media youtube
Legalitas usaha adalah standarisasi yang harus dipenuhi oleh pelaku usaha. Berdasarkan UU Nomor 20 tahun 2008 Usaha Mikro didefinisikan sebagai bentuk usaha produktif milik orang perorangan dan/atau badan usaha perorangan yang memenuhi kriteria Usaha Mikro sebagaimana diatur dalam Undang-Undang. Izin usaha merupakan suatu bentuk dokumen resmi dari instansi berwenang, yang menyatakan sah/dibolehkannya seseorang atau badan untuk melakukan suatu usaha atau kegiatan tertentu. Legalitas usaha sangat penting peranannya bagi Usaha Mikro Kecil dan Menengah (UMKM), sehingga mereka dapat terlindungi, adanya kepastian dalam berusaha dan menikmati kenyamanan serta keamanan yang patut mereka peroleh, agar dapat berkontribusi secara lebih nyata di dalam peningkatan nilai tambah produksi, penyediaan barang dan jasa kebutuhan masyarakat, penyerapan tenaga kerja dan diseminasi penumbuhan kewirausahaan. (Anggraeni, 2021)

Beberapa manfaat pentingnya legalitas usaha atau izin usaha bagi UMKM, yaitu :1) UMKM akan mendapatkan jaminan perlindungan hukum, 2) Memudahkan dalam mengembangkan usaha, 3) Membantu memudahkan pemasaran usaha. 4) Akses pembiayaan yang lebih mudah. 5) Memperoleh pendampingan usaha dari pemerintah yang berupa workshop, seminar maupun penyuluhan langsung ke lokasi usaha. (Primadhita \& Budiningsih, 2020). Adapun untuk perkembangan jangka Panjang Enggon Sin_Au_Qu telah memiliki Nomor Induk Berusaha (NIB) dan Ijin Usaha Mikro Kecil (IUMK).

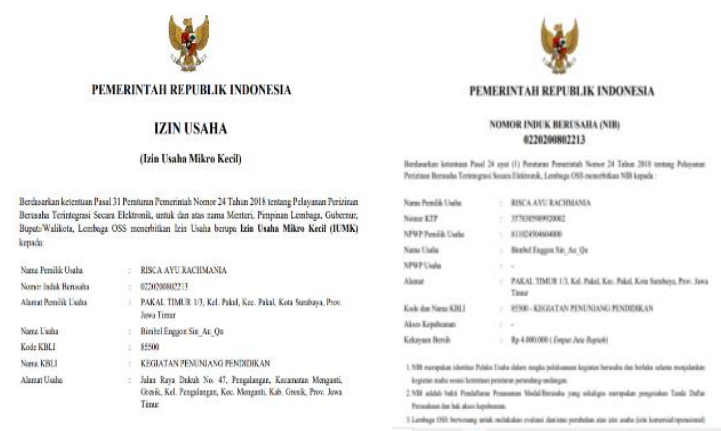


Gambar 18. Pengurusan legalitas usaha Izin Usaha Mikro Kecil dan Nomor Induk Berusaha

\section{KESIMPULAN}

Kesimpulan yang didapatkan dari hasil pengabdian kepada masyarakat pada mitra bimbel Enggon Sin_Au_Qu sebagai sociopreneurship antara lain : 1) Adanya pemberdayaan SDM tutor yang dilakukan dengan mengikuti pelatihan yang diadakan oleh pihak eksternal sehingga kualitas tutor semakin meningkat, 2) Sistem manajemen bimbel Enggon Sin_Au_Qu lebih terkoordinir sehingga komunikasi antara tutor, siswa, orang tua siswa dan pihak manajemen menjadi lebih selaras, 3) Dengan memasarkan dan mengenalkan produk jasa bimbel Enggon Sin_Au_Qu memanfaatkan sosial media seperti Instagram, Facebook dan Youtube, serta memanfaatkan website Enggon Sin_Au_Qu sehingga pasar produk menjadi lebih luas dan masyarakat lebih mengenal jasa yang ditawarkan. Penggunaan e-marketing juga memudahkan pelanggan untuk menggunakan jasa bimbel dan mengetahui spesifikasi produk jasa sesuai dengan kebutuhan pelanggan. Dengan demikian, Enggon Sin_Au_Qu sebagai wadah usaha yang mampu menumbuhkan potensi ekonomi yang dapat dinikmati berbagai pihak yang terlibat.

Berdasarkan pendampingan yang dilakukan oleh tim ada beberapa program yang belum optimal, salah satunya penggunaan YouTube sebagai media pembelajaran. Dengan demikian maka disarankan adanya optimalisasi pembelajaran secara asynchronous learning melalui YouTube sehingga dapat memberikan dorongan kepada masyarakat (siswa-siswi) untuk bergabung di Enggon Sin_Au_Qu.

\section{UCAPAN TERIMAKASIH}

Kegiatan KBMI ini terlaksana atas pendanaan dari Kemenristekdikti tahun 2020. Untuk ucapan terima kasih disampaikan kepada : 1) Tuhan yang Maha Esa 2) Kemenristekdikti tahun 2018. 3) Rektor Universitas Wijaya Putra Surabaya, Bapak H. Budi Endarto, SH., M. Hum 4) Rekan-rekan sejawat di Universitas Wijaya Putra Surabaya 5) Kakak Hardo Wahyudi sebagai pemilik usaha beserta tutor yang turut aktif berpartisipasi dalam kegiatan.

\section{REFERENSI}

Anggraeni, R. (2021). Pentingnya Legalitas Usaha bagi Usaha Mikro Kecil dan Menengah. Jurnal Hukum, 1(1), 77-83. https://doi.org/10.24114/jupiis.v11i2.13583

Bakhri, S., \& Futiah, V. (2020). Pendampingan dan Pengembangan Manajemen Pemasaran Produk UMKM Melalui Teknologi Digital Di Masa Pandemi Covid-19. Jurnal Loyalitas Sosial: Journal of Community Service in Humanities and Social Sciences, 2(2), 59. https://doi.org/10.32493/jls.v2i2.p59-70

Boediono, Budihabsari, E. A. (2016). Ekonomi Indonesia: dalam lintasan sejarah/ Prof Dr. Boediono: Penyunting, Esti A. Budihabsari (Boediono (ed.); Cetakan I,). Mizan Pustaka.

Corbanese, V., \& Rosas, G. (2016). Decent work for young people. In Jurnal Labor Economic (Vol. 7, Issue 3).

Hardilawati, W. laura. (2020). Strategi Bertahan UMKM di Tengah Pandemi Covid-19. Jurnal Akuntansi Dan Ekonomika, 10(1), 89-98. https://doi.org/10.37859/jae.v10i1.1934

Hendrawan, A., Sucahyowati, H., Cahyandi, K., Indriyani, \& Rayendra, A. (2019). Pengaruh Marketing Digital Terhadap Kinerja Penjualan Produk UMKM Asti Gauri di Kecamatan Bantasari Cilacap. Jurnal Administrasi Dan Kesekretarisan, 4(1), 53-60. http://www.jurnal.stiks-

tarakanita.ac.id/index.php/JAK/article/view/18 9/136

Jum'ati, N., Lukmana, A. H., Azizah, N. A., Slamet, J., Wulandari, S., Rachmania, R., \& Wulan, D. P. I. B. S. (2021). TANTANGAN DAN PELUANG PENGEMBANGAN BISNIS SKALA MIKRO OLEH IBU RUMAH TANGGA DI KALA PANDEMI. In N. Jum'ati (Ed.), Peran Perempuan Sebagai Pahlawan di Era Pandemi. GESI. 
Nugrahani, R. (2015). Peran desain grafis pada label dan kemasan produk makanan umkm. Jurnal Imajinasi, $\quad I X(2), \quad$ 127-136. https://journal.unnes.ac.id/nju/index.php/imaji nasi/article/view/8846

Prawanti, L. T., \& Sumarni, W. (2020). Kendala Pembelajaran Daring Selama Pandemic Covid-19. Prosiding Seminar Nasional Pascasarjana UNNES, 286-291.

Primadhita, Y., \& Budiningsih, S. (2020). Analisis Perkembangan Usaha Mikro Kecil Dan Menengah Dengan Model Vector Auto Regression. Jurnal Manajemen Kewirausahaan, $\quad 17(1), \quad 1$. https://doi.org/10.33370/jmk.v17i1.396

Sa'adah, N., Widiastuti, S. K., Fitria, V., Wau, T., \& Familiani, N. (2019). Reorientasi Karir di Masa Pandemi Covid 19 Bagi Fresh Graduate Perguruan Tinggi di Indonesia Nurus. 1-19.

Sejati, N. W., \& Prihastuti, R. (2018). Tingkat Kecemasan Sarjana Fresh Graduate Menghadapi Persaingan Kerja Dan Meningkatnya Pengangguran Intelektual.
Intuisi : Jurnal Psikologi Ilmiah, 4(3), 129133.

Stephanie, C. (2021). Riset Ungkap Lebih dari Separuh Penduduk Indonesia "Melek" Media Sosial Artikel ini telah tayang di Kompas.com dengan judul "Riset Ungkap Lebih dari Separuh Penduduk Indonesia 'Melek' Media Sosial."

Tekno.Kompas.

https://tekno.kompas.com/read/2021/02/24/08 050027/riset-ungkap-lebih-dari-separuhpenduduk-indonesia-melek-media-sosial

Tabi'in, A. (2020). Problematika Stay At Home Pada Anak Usia Dini Di Tengah Pandemi Covid 19. Jurnal Golden Age, 4(01), 190-200. https://doi.org/10.29408/jga.v4i01.2244

Wardhana, A., Kharisma, B., \& Ibrahim, Y. F. (2019). Pengangguran usia muda Di Jawa Barat (Menggunakan data Sakernas) [Youth unemployment in West Java (Using Sakernas data)]. E-Jurnal Ekonomi Dan Bisnis Universitas Udayana, 9(8), 1049-1062. 